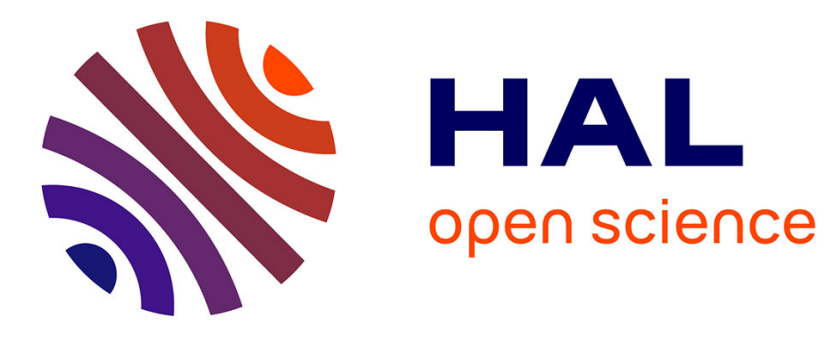

\title{
Pluractionality and distributive numerals
}

Jeremy Kuhn

\section{To cite this version:}

Jeremy Kuhn. Pluractionality and distributive numerals. Language and Linguistics Compass, 2019, 13 (2), pp.e12309. 10.1111/lnc3.12309. ijn_03053129

\section{HAL Id: ijn_03053129 \\ https://hal.science/ijn_03053129}

Submitted on 10 Dec 2020

HAL is a multi-disciplinary open access archive for the deposit and dissemination of scientific research documents, whether they are published or not. The documents may come from teaching and research institutions in France or abroad, or from public or private research centers.
L'archive ouverte pluridisciplinaire HAL, est destinée au dépôt et à la diffusion de documents scientifiques de niveau recherche, publiés ou non, émanant des établissements d'enseignement et de recherche français ou étrangers, des laboratoires publics ou privés. 


\title{
Pluractionality and distributive numerals
}

\author{
Jeremy Kuhn
}

\author{
Institut Jean Nicod, Département d'études cognitives, \\ ENS, EHESS, CNRS, PSL Research University
}

November 3, 2018

\begin{abstract}
Cross-linguistically, morphological marking on verbs and nouns can indicate that a plurality of events or individuals is distributed with respect to another plurality. In these verbal domain, these have been called pluractionals; in the nominal domain, they have been called distributive numerals or dependent indefinites. This paper discusses recent semantic approaches to the cross-domain parallels between the two phenomena. After establishing some formal and typological background, we introduce a number of recent compositional challenges that have been introduced by these patterns.
\end{abstract}

Keywords: pluractionality, distributive numerals, dependent indefinites, distributivity, plurality, event semantics, sameldifferent

\section{Introduction}

In natural language, there are many ways to introduce pluralities. Perhaps the simplest way is through morphological marking-for example, changing singular zebra to plural zebras. In other constructions, however, a plurality may be generated through more complex means, through an interaction with another plural. In (1), for example, 'one book' is morphologically singular, and yet we infer that there are a plurality of books, one per girl. As it turns out, a wide range of languages have a way of morphologically indicating this kind of dependent plurality. In languages as diverse as Hungarian, Telugu, and Kaqchikel Mayan, it is possible to communicate this dependency by reduplicating a numeral: one-one, two-two, three-three, and so on. The Kaqchikel sentence in (2) means that there are three tortillas per person. In the literature, these inflected numerals have been variously called distributive numerals or dependent indefinites (Gil 1982; Farkas 1997).

(1) The girls each read one book.

(2) Xeqatij ox-ox wäy we-eat three-three tortilla 'We ate three tortillas each.' 
Many languages of the world also provide a grammatical way to encode pluractionality, that is, a plurality of events. This might be one thing happening again and again, or many things happening at the same time. For example, in Upriver Halkomelem, the verb yáleq' is the pluractional form of the verb meaning 'to fall'. The sentence in (3) can be used to describe a situation where many trees fell down at the same time, or where the same tree fell down multiple times, but not one in which one tree fell down one time.

(3) yáleq' -et -es te theqát fall.pl -tr. $-3 \mathrm{~S}$ det. tree

'He/they felled the tree(s).'

(Upriver Halkomelem, Thompson 2009)

Distributive numerals and pluractional verbs pertain to different syntactic categories and different semantic domains: distributive numerals modify noun phrases to indicate a plurality of individuals; pluractional morphemes modify verb phrases to indicate a plurality of events. However, despite these differences of domain, the two phenomena share a number of formal and typological semantic properties. In both cases, a hallmark property is the fact that the plurality in question is defined relative to another plurality in the sentence or context. Just as the plurality of tortillas in (2) is defined relative to the plural subject, the plurality of falling events in (3) is defined relative to a plural set-either a plurality of trees that fell or a plurality of times at which a tree fell. The relation between these two pluralities is described in $\$ 2$.

Distributive numerals and pluractional verbs also share important compositional properties. Of note, these properties turn out to be different from those of generalized quantifiers like every child or floated adverbial each, as in (1). In any of these cases, the final sentential meaning is one that involves distribution, but the compositional way in which this meaning is derived is rather different, leading to different empirical patterns. In short, generalized quantifiers and adverbial each are pluralizing operators, that sum atomic objects into plural objects. In contrast, distributive numerals and pluractional verbs check that there is a plurality, but don't create one. These compositional differences, and the patterns they lead to, are described in $\S 3$. Up until this point, the formal generalizations sketched will reflect converging analyses from a range of theoretical traditions.

In $\S 4$, we turn to a recent debate in the literature, regarding a pattern that could be called 'distributive concord,' in which a distributive numeral or pluractional verb appears to be redundant with a distributive operator like each student. We discuss one important division in the analyses of these cases, which either puts the explanatory burden on the syntax or on the semantics. After giving some recent arguments in favor of a semantic analysis, we lay out some further choicepoints within the set of semantic analyses.

In $\S 5$, we outline some new avenues of research, including connections to phenomena elsewhere. First, we show that the behavior of pluractional verbs and distributive numerals is parallel to that of the adjectives same and different, another rich domain of semantic research. Second, we turn to cases of 'event-internal' pluractionals, which show distinct semantic behavior from canonical cases of pluractionality. 


\section{Dimensions of distribution}

Both pluractionals and distributive numerals relate to pluralities that are defined based on their distributive relationship with a second plurality. Terminologically, we call this second plurality the $k e y$, while the plurality introduced by the the pluractional or the distributive numeral is the share. For example, (4) provides a Turkish sentence with the distributive numeral ïçer, 'three each'; the sentence is compatible with a scenario in which six suitcases are distributed across two men. On this reading, the share-i.e., what is distributed-are the suitcases, and the key-i.e., what the suitcases are distributed across—are the men.

(4) Iki adam üçer bavul taşıdı two man three-DIST suitcase carried

Two men carried three suitcases (each).

(Turkish, Gil 1982)

In the case of distributive numerals, the distributive share is the plurality of individuals associated the noun phrase. In the case of pluractional verbs, the distributive share is the plurality of events associated with the verb. In both cases, however, there may be a choice regarding the distributive key. For example, in the example in (3), the plurality of events may be distributed across participants (i.e. different trees falling down), or across times (i.e. one tree falling down repeatedly). Distribution across participants is called the participant key reading, and distribution across times is called the temporal key reading. In some cases, distribution is also allowed over regions of space, or contextually salient groupings.

\subsection{Typological variation}

One of the strong generalizations emerging from typological work on pluractionals is that a particular morpheme in a given language may specify what is allowed as the distributive key (Cusic 1981; Lasersohn 1995). While the Halkomelem example in (3) is underspecified, allowing distribution across participants or time, in the related language Squamish, the pluractional made by reduplicating verb xwet, 'jump,' specifies distribution across time; the sentence cannot be used to describe a single occasion on which each individual jumped.

(5) chet xwet-xwit-im

1S.PL RED-jump-INTR

'We are jumping.'

(Squamish, Bar-El 2002)

A single language may have pluractional morphemes that specify different distributive keys. For example, in French Sign Language, -rep (exact repetition) requires distribution across time, and -alt (alternating hands) requires distribution across participants (Kuhn and Aristodemo 2017). Sentence (7), for example, becomes ungrammatical with singular object 'ONE WORD.'

(6) ONE PERSON FORGET-rep ONE WORD.

'One person forgot one word repeatedly.'

(7) ONE PERSON FORGET-alt SEVERAL WORDS.

'One person forgot several words.'

(LSF, Kuhn and Aristodemo 2017) 
In fact, the range of meanings that are generated by pluractional inflection goes beyond the strictly distributive; in some languages, the same set of suffixes that mark distribution can also be used to mark a variety of related interpretations, like increased effort or excessive action, such as Dyirbal balbalgan 'hit too much', compared to balgan 'hit' (Dixon 1972). See Cusic (1981) for an exhaustive typology of pluractional meanings.

For distributive numerals, a similar situations holds. For distributive numerals in Telugu (Balusu 2005), Tlingit (Cable 2014), and Kaqchikel (Henderson 2014), the distributive key may be participants or space-time segments. In Hungarian, the dependent existential egy-egy, 'one-one' allows the same choices, but dependent numerals greater than one like két-két, 'two-two,' only allow the participant key reading (Farkas 2015).

(8) Minden gyerek hozott \{egy-egy/két-két $\}$ könyvet. Every child brought $\{$ one-one/two-two $\}$ book. 'Each child brought \{one book/two books\}.'

A politikus mindig megtapsolt egy-egy ellenzéki hozzászólást. The politician always applauded one-one opposition comment. 'Always, the politician applauded an opposition comment.'

* A politikus mindig megtapsolt két-két ellenzéki hozzászólást. The politician always applauded two-two opposition comment.

(Hungarian, Farkas 2015)

A related point of variation is whether or not this distributive key may be implicitly inferred (Henderson 2014). In Kaqchikel and Hungarian, distributive numerals require their distributive key to appear overtly in the sentence; in Telugu and Tlingit, the distributive key may be inferred from context, provided that this results in a 'cognitively natural' partition (Cable 2014). Thus, the Telugu sentence in (11) allows an implicitly-inferred temporal-key reading, while the Kaqchikel sentence in (12), without an overt licensor, is ungrammatical.

(11) Raamu renDu-renDu kootuluni cuuseeDu

Ram two-two monkeys saw

'Ram saw two monkeys at each time/location.'

(Telugu, Balusu 2005)

* Xe'inchäp ox-ox wäy.

I-handle three-three tortilla

'I took three tortillas each.'

(Kaqchikel, Henderson 2014)

Although similar patterns hold for both pluractionals and distributive numerals, it is interesting to note a few differences in these typologies. First, pluractionals sometimes allow a broader range of meanings, including intensification or culmination, mentioned above. Second, there is variation with respect to the 'default' distributive key. For distributive numerals, a temporal key reading may or may not be available, but it seems that a participant key reading always is. For pluractional verbs, a participant key reading may or may not exist, but if it does, it is very likely that a temporal key reading does, too. The one counterexample to this tendency of which I am aware is the pluractional marker -alt in French Sign Language, which only has a participant key reading. (And here, it is notable that other iconic properties are introduced with the use of two hands; see Lepic et al. 2016.) 


\subsection{Underspecification or ambiguity?}

The way that we have characterized pluractionality and distributive numerals above makes reference to a second plurality (the distributive key). However, as emphasized by Cable (2014), the link between these two pluralities may be rather indirect. As an example, consider the plural of the English event-denoting noun party, as in (13). This sentence may be true if the same group of students threw multiple parties throughout the year, and also if multiple subgroups of students threw simultaneous parties on a single evening. These contexts seem to correspond to what we have called the 'temporal-key' and 'participant-key' readings, but no standard analysis of the plural suffix /-s/ makes reference to a distributive key. Rather, the distribution across participants, space, or time is just a necessary condition for what it means to be two distinct events.

\section{(13) The students threw many parties.}

Motivated by this observation, Cable (2014) argues that a similar situation holds for distributive numerals: for him, all readings of distributive numerals are 'event-key' readings, and the variety of compatible contexts arises from the different spatio-temporal ways in which these events might be distinguished. Cable (2014) shows that this kind of analysis is particularly adapted to Tlingit, in which distributive numerals never lexically specify a participant or temporal key reading.

On the other hand, we have just seen that some languages $d o$ identify a particular dimension of distribution. How do we account for these patterns? One option is to have further specification of the plural event. Just as the English noun phrase 'repeated parties' restricts the set of events to those temporally distributed in time, a pluractional verb or distributive numeral can specify this information in its lexical entry. Lasersohn (1995) spells out such an analysis for pluractional verbs, which may specify that the subparts of a plural event are distributed across time, space, or participants.

For some languages, it has also been argued that distributive numerals contain a null pronoun that is anaphoric to their distributive key (see, e.g. Zimmermann 2002 for English binominal each, Brasoveanu and Farkas 2011 for distributive numerals more generally). Kuhn (2017) argues that this co-indexation is made morphologically overt in American Sign Language, in which a distributive numeral, like ONE-arc, is required to be spatially co-indexed with its plural licensor. In (14), lowercase 'a' indicates spatial colocation.

\section{BOYS THEY-arc-a READ ONE-arc-a BOOK.}

'The boys read one book each.'

(ASL, Kuhn 2017)

These points of view are not necessarily in conflict. It may be the case that distributive numerals in one language incorporate a null pronoun, and that a similar construction in another language does not. In any case, all these morphemes share the common property of event plurality, and the potential for distributive association with another plural in the sentence.

\section{Plurality filters}

The English and Hungarian sentences in (15) receive near-identical truth conditions, associating each child with a book. Likewise, the English and LSF sentences in (16) receive near-identical truth 
conditions, associating each of my friends with an arriving event. However, the compositional way in which these meanings are derived turns out to be quite different in the two cases.

(15) a. The children each brought one book.

b. A gyerekek hoztak egy-egy könyvet. The children brought one-one book

a. My friends each arrived.

b. MY FRIENDS ARRIVE-alt.

(LSF, Kuhn and Aristodemo 2017)

The analytical difference boils down to a difference between pluralizing operators and plurality filters. Pluralizing operators sum objects together to make new pluralities. In contrast, plurality filters restrict a set to only the plural objects, but they do not add any new elements to the set. Examples of these two kinds of operations are shown in (17). Here, $x \oplus y$ (the sum of $x$ and $y$ ) is defined as the smallest object that both $x$ and $y$ are part of.

a. Pluralizing operators sum together the objects in a set $\{a, b, c\} \quad \rightarrow \quad\{a, b, c, a \oplus b, a \oplus c, b \oplus c, a \oplus b \oplus c\}$

b. Plural filters restrict a set to only its plural objects $\{a, b, c, a \oplus b, a \oplus c, b \oplus c, a \oplus b \oplus c\} \quad \rightarrow \quad\{a \oplus b, a \oplus c, b \oplus c, a \oplus b \oplus c\}$

Note: because pluractionality deals with event pluralities, it will be convenient to me to use event semantics (Davidson 1967; Parsons 1990) and an algebraic semantics for plurals (Link 1983; Krifka 1998). However, the operator/filter distinction can be formulated in other frameworks. In standard truth-conditional semantics, e.g., distributive operators quantify universally over their scope. Plurality filters impose an intersective restriction on a set, removing non-plural individuals.

English adverbial each, like German jeweils and similar items in other languages, is typically taken to be a distributive/pluralizing operator (Zimmermann 2002, i.a.). On an event-semantic analysis, the denotation of 'brought one book,' only contains events that involve a single atomic book, as in (18). But, since each sums events in the denotation of its complement-including ones with different themes - the sentence in (15a) admits events in which multiple books were brought (see, e.g. Champollion 2015, building on Link 1987).

(18) $\llbracket \operatorname{brought}$ one book $\rrbracket=\lambda e .{ }^{*} \operatorname{bring}(e) \wedge{ }^{*} \operatorname{book}(\operatorname{theme}(e)) \wedge|\operatorname{theme}(e)|=1$

In contrast, pluractional verbs and distributive numerals act as plurality filters. The definition in (19) sketches a very simple definition for pluractional morphemes; here, $|e|$ returns the number of atomic parts of $e$; additional conjuncts can specify the meaning further, such as adding restrictions on how the subevents are distributed. On an event-semantic analysis, the denotation of arrive contains all singular and plural arriving events. The sentence in (16b) filters out only those plural events in which multiple people arrived. Since the semantic contribution of the pluractional is included as a separate conjunct, no events are returned that were not included in the original set.

$\llbracket$-PLURACT $\rrbracket=\lambda V e . V(e) \wedge|e|>1 \wedge \ldots$

'Given a predicate $V$, return the set of non-atomic $V$-ing events.'

(cf. Lasersohn 1995; Kuhn and Aristodemo 2017) 
Empirically, the fact that pluractionals are plurality filters can be observed in two related properties. First, pluractionals cannot induce variation in a plain indefinite. Second, pluractionals and distributive numerals can appear redundantly in a sentence without multiplying the distributive effect. These properties, and their contrast with adverbial each, are shown in Sections 3.1 and 3.2.

\subsection{No variation of plain indefinites}

When a plain indefinite (e.g., someone, a student, two apples), appears under a distributive operator, the interpretation of the indefinite can co-vary with the distributive operator. On the surfacescope reading of (20), each professor is associated with a potentially different student.

(20) Every professor invited a student.

Across a variety of languages, a number of authors have observed that pluractional morphemes do not have this property (see Yu 2003 for Chechen, van Geenhoven 2004 for West Greenlandic, Laca 2006 for Spanish, Henderson 2014 for Kaqchikel, Kuhn and Aristodemo 2017 for French Sign Language). The French Sign Language pair in (21) illustrates the contrast between distributive operators and pluractional markers in this respect. In (21a), the distributive operator EVERY-DAY can scope over the indefinite 'ONE WORD' allowing the words to vary day by day. In contrast, although the pluractional morpheme -rep may also indicate an event recurring over time, these events must involve the same word on each occasion. This contrast is particularly notable with what Cabredo Hofherr and Laca (2012) call 'once-only' predicates - denoting events that can only happen a single time to an individual. In Chechen, for example, lilxira is the pluractional form of the verb 'explode'; the sentence in (22) can only be used to describe the unlikely scenario in which the same bomb exploded multiple times.

a. EVERY-DAY JEAN ONE WORD FORGET.

$\checkmark$ many words $\quad \checkmark$ one word 'Every day, Jean forgot one word.'

b. JEAN ONE WORD FORGET-rep.

*many words $\checkmark$ one word 'Jean forgot one word repeatedly.'

(LSF, Kuhn and Aristodemo 2017)

Bomba lilxira bomb.SG explode.PLR

'A/the bomb exploded repeatedly.'

(Chechen, Wood 2007)

Analytically, this can be understood on an analysis of pluractional markers as plurality filters. In (21), the constituent 'ONE WORD FORGET' denotes the set of singular or plural events involving a single word; the pluractional marker -rep filters out only those plural events distributed over time. Notably, this returns a subset of the original set, so these events, too, involve only a single word.

\subsection{Innocent redundancy}

When distributive operators are nested one inside another, this gives rise to 'doubly-distributive' meanings. For example, if I have three children, then (23a) entails that at the end of a week, there have been 21 hugs ( $=3$ children $\times 7$ mornings). In (23b), if there are $n$ professors and $m$ classes, 
then there are $n \times m$ nominations. The expressions every $X$, adverbial each, and per $X$ are all distributive operators that introduce their own level of distribution.

a. I hug each of my children every morning.

b. The professors each nominated one student per class.

In contrast, pluractionals and distributive numerals may appear redundantly in a sentence without multiplying distributivity (Gil, 1982; Oh, 2006). Sentence (24) provides an example from Kaqchikel; here, the sentence includes both the pluractional marker -ala' and a distributive numeral ju-jun, 'one-one.' The two pluractionality markers reside peaceably in the same sentence; both the events and books vary with respect to a single distributive key-times or locations.

(24) Xinkan-ala' ju-jun wuj.

I-search-LA' one-one book

'I looked for a book on each occasion.'

(Kaqchikel, Henderson 2014)

Similarly, multiple distributive numerals may occur together without compounding distributive force. The Korean sentence in (25), where ssik marks two distributive numerals, allows a reading in which men and boxes are both distributed with respect to the same event-based distributive key.

(25) Namca twu-myeng-ssik-i sangca sey-kay-ssik-ul wunpanhayssta

man two-Cl-Dist-Nom box three-Cl-Dist-Acc carried

'Two men carried three boxes on each occasion.'

(Korean, Oh 2006)

Again, the difference in behavior can be explained by the operator-filter distinction. Pluralizing operators sum events together, so nesting multiple operators will compound the effect, by summing together events that have already been pluralized. (Or, in truth-conditional semantics, by having nested universal quantifiers.) On the other hand, plurality filters contribute intersective meanings, so they may further refine the attributes of a plural event, but the repeated specification of pluractionality is innocently redundant. In (24), the pluractional verb and the distributive numeral both check that there is a plurality of events. Each item may specify additional properties of the event-for example, the distributive numeral specifies the number of books involved in each sub-event; however, checking for plurality twice does not 'multiply' distributivity. This can be seen schematically in (26), where syntactically nested pluractionality operators can be simplified to a single conjunct checking for event plurality. (Formally, simplification is possible since logical conjunction is associative, commutative, and idempotent).

$$
\begin{aligned}
\operatorname{PLURACT}[\ldots \operatorname{PLURACT}(V) \ldots] & =\lambda e \cdot[V(e) \wedge|e|>1 \wedge \ldots] \wedge|e|>1 \wedge \ldots \\
& =\lambda e \cdot V(e) \wedge|e|>1 \wedge \ldots
\end{aligned}
$$

\subsection{Diverse frameworks}

The properties described above are shared across analyses from a wide range of theoretical frameworks, including standard truth-conditional semantics, event semantics, and dynamic semantics. 
The 'operator' view of adverbial each and related constructions, for example, can be seen in Zimmermann (2002), Champollion (2015), and van den Berg (1996), each of which comes from a different theoretical tradition. The 'filter' view of pluractionals and distributive numerals appears in Lasersohn (1995), Cable (2014), and Kuhn and Aristodemo (2017), which use event semantics, as well as Henderson (2014) and Kuhn (2017), which use dynamic semantics. One notable shared property of event semantics and dynamic semantics is that they represent sub-sentential semantic structure as the conjunction of propositional terms, which is convenient for analyzing the formal properties of pluractionality described above.

\section{Licensing by distributive operators}

As seen in $\$ 2$, pluractionals and distributive numerals introduce a plurality of objects that is in a distributive relationship with a second plurality. We saw that participant key readings entail distribution across event participants. One consequence of this is that participant key readings must be licensed by the presence of a plural elsewhere in the sentence. Example (27) provides a minimal contrast (repeated from (2) and (12)); when all other arguments in the sentence are singular, the distributive numeral makes the sentence ungrammatical, similarly to the English translation.

$$
\begin{aligned}
& \text { a. Xeqatij ox-ox wäy } \\
& \text { we-eat three-three tortilla } \\
& \text { 'We ate three tortillas each.' } \\
& \text { b. * Xe'inchäp ox-ox wäy. } \\
& \text { I-handle three-three tortilla } \\
& \text { 'I took three tortillas each.' }
\end{aligned}
$$

(Kaqchikel, Henderson 2014)

With respect to licensing, pluractionals and distributive numerals turn out to show a surprising interaction with distributive operators like English each (or Kaqchikel chikijujunal), that distribute down to atoms. In general, quantifiers like each yield the inference that the predicate holds of each atomic individual, schematized in (28). This inference pattern is exhibited in the ungrammaticality of distributive operators with collective predicates, as in (29). It is ungrammatical to say 'Sam gathered in the market,' 'Gabe gathered in the market,' and so on, and so it is equally ungrammatical to say that 'Each of them gathered in the market' (or the Kaqchikel equivalent).

(28) 'Each individual Xed' $\rightarrow$ 'Sam Xed' and 'Gabe Xed' and 'Oliver Xed' ...

(29) * Chikijujunal xkimol ki' pa k'ayb'al. each gathered REFL in market 'Each of them gathered in the market.'

(Kaqchikel, Henderson 2014)

Surprisingly, however, pluractionals and distributive numerals are licensed by distributive operators, as seen in (30). As has been observed by a number of authors (notably Henderson 2014; Kuhn 2017), this poses a compositional puzzle, since the 'unpackaged' version of (30), 'X hugged one-one dog, Y hugged one-one dog, and so on,' would be ungrammatical, just like (27b). 
For distributive numerals, this licensing puzzle has been well-documented, including for Hungarian (Farkas 1997), Telugu (Balusu 2005), Korean (Oh 2006), Tlingit (Cable 2014), Kaqchikel (Henderson 2014), and American Sign Language (Kuhn 2017). For pluractional marking on verbs, the property has been less well documented, but has been reported for both participant key and temporal key distribution in French Sign Language (Kuhn and Aristodemo 2017).

a. BOY EACH FORGET-alt BRING CAMERA.

'Each boy forgot to bring a camera.'

b. EVERY-DAY ONE BOOK JEAN GIVE-1-rep.

'Every day, Jean gave me one book.'

(LSF, Kuhn and Aristodemo 2017)

\subsection{Two points of view}

The puzzle above opens two attractive but opposing avenues for analysis, both of which are represented in the literature: an analysis based on syntactic agreement, and an analysis based on scope.

On an agreement-based analysis, the pattern exemplified in (30) and (31) is viewed as a kind of 'distributive concord.' Similar to standard analyses of negative concord (Zeijlstra, 2004), what appears as pluractional marking on the numeral or verb is the expression of a semantically uninterpreted feature, with a syntactic constraint that requires it to appear in the scope of a higher (interpreted) distributivity operator. Thus, the sentence in (32) would be assigned the LF in (33), in which the distributive numeral is syntactically licensed by a silent $\mathrm{D}$-operator. This point of view has been most clearly articulated by Oh (2006) and Kimmelman (2015).

(32) Namca-tul-i sangca twu-kay-ssik-ul wunpanhayssta.

Man-Pl-Nom box two-Cl-Dist-Acc carried

'Men carried two boxes each.'

(Korean, Oh 2006)

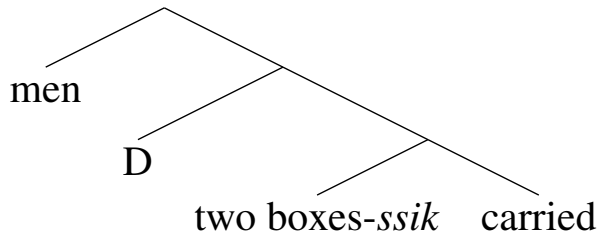

On such an analysis, examples like (30) are unsurprising, since the only difference is that the distributive operator is overt. Two critical properties should be observed about this line of analysis. First, even when there is no overt distributivity operator like each, as in (32), distributive numerals and pluractional verbs signal the presence of a silent distributivity operator in the sentence. Second, distributive numerals and pluractional verbs appear structurally below this distributive operator.

On a scope-based analysis, there is no reliance on a covert distributive operator: the pluractional verb or distributive numeral itself contributes the plurality inference. In order to account for licensing by distributive operators, as in (30), a mechanism of scope-taking allows the pluractional 
morpheme to be interpreted at a higher structural position than the distributive operator. The effect is one of innocent redundancy, like what is described in \$3.2. First, the distributive operator pluralizes a predicate, resulting in a set of plural events. Then, the pluractional morpheme applies as a filter on this set; notably, the plurality check is satisfied by the output of the distributive operator. The sentence in (34) would thus be assigned the LF in (35). This point of view has been advocated for by Henderson (2014), Kuhn and Aristodemo (2017), and Kuhn (2017).

EACH INVITE-alt GIRL.

'Each of them invited a girl.'

(LSF, Kuhn and Aristodemo 2017)

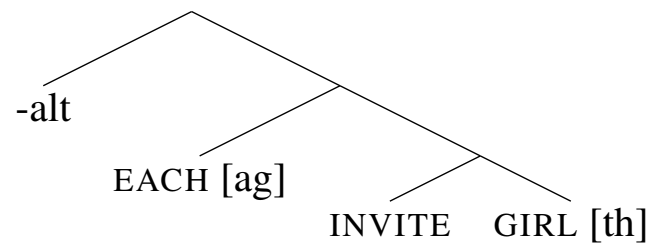

On this analysis, if a distributive operator appears in the sentence, the pluractional morpheme or distributive numeral necessarily takes scope above it.

\subsection{Against silent D-operators: the behavior of plain indefinites}

One of the critical components of the agreement-based analysis is the obligatory presence of a silent distributive operator in some environments. Several recent analyses argue against the presence of such an operator by looking at the behavior of plain indefinites in these environments.

Henderson (2014) develops such an argument by looking at the interaction of pluractionals and distributive numerals in Kaqchikel. In Kaqchikel, distributive numerals are not licensed when all other elements in a sentence are singular, as shown in (36), repeated from (12). On the other hand, they are allowed in sentences when the verb shows pluractional marking, as shown in (37), repeated from (24).

* Xe'inchäp ox-ox $\quad$ wäy.

I-handle three-three tortilla

'I took three tortillas each.'

Xinkan-ala' ju-jun wuj.

I-search-LA' one-one book

'I looked for a (different) book on each occasion.'

(Kaqchikel, Henderson 2014)

Pluractional verbs are thus sufficient to license distributive numerals in Kaqchikel. Under an agreement-based analysis, this means that there must be a distributivity operator in the environment embedding the distributive numeral in (37). If this is indeed the case, then it should be possible for a plain indefinite in the same environment to vary with respect to this distributivity operator. This turns out not to be the case. Similarly to pluractionals in other languages, pluractional verbs in Kaqchikel cannot induce variation in a plain indefinite (cf. §3.1). The sentence in (38) can only describe a scenario in which a single book was looked for several times. 
Kuhn (2017) develops a similar argument using sentences in which a distributive numeral appears alongside a plain indefinite. The Hungarian sentence in (39) contains a distributive numeral, which - under an agreement-based analysis - indicates the presence of a silent distributive operator. In (39), however, the distributive numeral is conjoined to a plain indefinite. The agreementbased analysis thus predicts that the plain indefinite, too, must be trapped under the distributive operator, entailing two appetizers per student. As it turns out, though, the sentence easily allows a reading in which only two appetizers were ordered in total.

(39) A diákok két elóételt és egy-egy fóételt rendeltek. The students two appetizers and one-one main-dish ordered 'The students ordered two appetizers one main dish.'

(Hungarian, Kuhn 2017)

In both cases, the absence of variation in plain indefinites provides evidence that the distributive numerals in (37) and (39) are appearing without the presence of a higher distributive operator.

\subsection{Iconicity and scope in LSF}

In LSF, Kuhn and Aristodemo (2017) show that pluractional markers display iconicity: the rate at which a verb is reduplicated indicates the relative rate at which the event happened. Formally, this can easily be incorporated into the definition. An iconic predicate describes a set of events by reference to the phonetic form $\Phi$; as an event predicate, it is thus of the correct type to be added as a modifier to the pluractional morpheme, as in (40).

$$
\llbracket \text {-alt/-rep } \rrbracket=\lambda V \lambda e . \quad \underbrace{V(e) \wedge|e|>1 \wedge \ldots}_{\text {Logical component }} \wedge \underbrace{\operatorname{Icon}^{\Phi}(e)}_{\text {Iconic component }}
$$

/-alt/ and /-rep/ give the set of non-atomic $V$-ing events (with other specified logical properties), which are distributed temporally in the manner shown'

Iconicity provides another way to resolve the theoretical question regarding the hierarchical position of the pluractional morpheme. Kuhn and Aristodemo (2017) show that the iconic meaning of the pluractional marker in ASL and LSF can be interpreted with narrow scope or wide scope: for example, accelerating reduplication of a verb can indicate the rate at which each individual performed an event, or it can indicate the overall rate at which events were performed by members of a plural licensor. Critically, they show that the level at which the iconic component is evaluated is exactly the structural position at which the logical component is evaluated. In particular, in the case of distributive operators, a slow movement of /-alt/ under EACH must denote an event which happens slowly from a global perspective, indicating that the pluractional morpheme is evaluated at a high structural position. 
a. $\quad \checkmark$ 'Each boy gave me books, which happened slowly from a global perspective.'

b. * 'Each boy gave me books at a slow rate. (Because there are so many boys, I received books quickly.)'

The interpretation of iconic information in sign language thus provides evidence for a structure in which the pluractional morpheme scopes above the distributive operator, as in the LF in (35), as opposed to one in which it takes scope below the distributive operator, as in the LF in (33).

\subsection{How to take scope}

If pluractional morphemes and distributive numerals are evaluated as though at a higher structural position, by what semantic process does this scope-taking occur? At least three proposals have been made in the literature: implicature, standard scope-taking, and dynamic postsuppositions.

Balusu (2005) suggests that the plurality inference of distributive numerals may be an implicature, analogous to an implicature-based account of plural nouns (Zweig, 2005). As an implicature, the meaning is evaluated at the level of the sentence. Henderson (2014) argues that an analysis in terms of conversational implicature falls short on a number of fronts, including the behavior of distributive numerals in embedded contexts and the fact the plurality inference can never be canceled. Nevertheless, an analysis in terms of conventional implicature may still be a viable option.

Kuhn (2017) proposes that, at least for distributive numerals, the process is exactly the same as standard quantifier scope (i.e. quantifier raising or equivalent). In particular, quantifiers are known to be sensitive to scope-islands out of which they cannot take scope. Cross-linguistically, distributive numerals have been shown to be sensitive to a similar locality constraint: distributive numerals need to appear in the same clause as their plural licensor (Choe, 1987; Oh, 2006; Zimmermann, 2002; Cable, 2014; Kuhn, 2017). Sentence (43) provides an example from Hungarian, in which an if-clause blocks the licensing of a distributive numeral. Whatever mechanism allows the plurality inference to be interpreted high, it is thus sensitive to at least some of the locality constraints that delimit quantifier scope.

(42) Minden professzor két-két diákról mondta, hogy meglepné ha 〈diplomát szereznének〉. every professor two-two students-of said that surprised if diploma receive 'Every professor said of two students that he would be surprised if they graduated.'

* Minden professzor azt mondta, hogy meglepné, ha 〈két-két diák diplomát szerezne $\rangle$. every professor DEM said that surprised if two-two student diploma receive 'Every professor said that he would be surprised if two students graduated.'

(Hungarian, Kuhn 2017)

Finally, Henderson (2014) proposes an analysis of distributive numerals in terms of 'postsuppositions,' defined in a dynamic semantic system. If presuppositions check that a property holds of a context before a proposition is evaluated, a postsupposition is required to hold of a context after a proposition is evaluated. In the case at hand, the plurality inference of distributive numerals is evaluated after the distributive operator has been applied. See Charlow (to appear) for a discussion of the relationship between postsuppositions and standard quantifier scope. 
For the case of pluractional verbs, the analytical situation is less clear; note, for example, that quantifier raising is not an operation generally assumed for verbal affixes. In the verbal domain, there has also been sparser documentation of licensing by distributive operators, making the empirical landscape less sure. On the other hand, similar phenomena have been discussed for the case of verbal aspect. Deo (2009) and Ferreira (2016) discuss the interaction between imperfect aspect and temporal quantifiers. They argue that, in order to get the correct meaning for sentences like (44), the imperfect aspect must be interpreted at a higher position than the temporal quantifier sempre, 'always.' No explicit scope-taking mechanism is proposed, but the fact that aspect-marking is an inflectional morpheme opens the possibility that it is base-generated at this higher structural position. (Pluractional marking, in contrast, is generally considered a derivational morpheme.)

(44) Quando Pedro escrevia um artigo, ele sempre o submetia a um periódico. When Pedro wrote-IMP an article, he always it submitted-IMP to a periodical 'When Pedro wrote an article, he always submitted it to a periodical.'

(Portuguese, Ferreira 2016)

For both distributive numerals and pluractional verbs, more precise generalizations about this scope-taking mechanism will likely emerge with further fieldwork on spoken and sign languages.

\section{Further directions}

This section briefly describes some further directions to the study of pluractionality and distributive numerals, including formal parallels with the adjectives same and different, and cases of 'eventinternal' pluractionality.

\subsection{Parallels with same and different}

The adjective same is known to be ambiguous between an 'external' and an 'internal' reading. On the external reading, sentence (45) compares the dogs to another individual in context ('My pet rabbit licked a cat....'); on the internal reading, it compares the dogs to each other. Critically, the internal reading of (45a) is only licensed by the presence of a plural elsewhere in the sentence. Out of the blue, the sentence in (45b) is ungrammatical; we are left asking, 'As who?'

(45) a. All the dogs licked the same cat.

b. * Fido licked the same cat.

The adjective same shows striking parallels with pluractionals and distributive numerals. First, Hardt et al. (2012) and Hardt and Mikkelsen (2015) observe that sentences with same necessarily involve multiple events - that is, they are pluractional. The sentence in (46) cannot be used to describe a single event in which Mary sold John a book.

(46) John bought and Mary sold the same book.

(Barker 2007) 
On its internal reading, same also shows licensing patterns similar to the ones above. The contrast in (45) shows that the internal reading must be licensed by a plural licensor, but, just as for distributive numerals and pluractionals, this licensor may be an operator that distributes down to atomic individuals, as in (47).

(47) Each student recited the same poem.

Finally, Kuhn (2017) shows that in American Sign Language, the adjectives same and different are morphologically unified with distributive numerals. In each case, distributivity is marked by reduplication or movement across an area of space. Spatial co-indexation with another plural is used to specify the distributive key. Thus, in (48), the arc-movement of ONE or SAME over location ' $a$ ' (where the boys were indexed) yields a distributive reading for (48a), and an obligatory internal reading of (48b).

$$
\begin{aligned}
& \text { a. ALL-a BOY READ ONE-arc-a BOOK. } \\
& \text { 'All the boys read one book.' } \\
& \text { b. ALL-a BOY READ SAME-arc-a BOOK. } \\
& \text { 'All the boys read the same book.' }
\end{aligned}
$$

(ASL, Kuhn 2017)

Like pluractionals and dependent indefinites, the patterns exemplified by same and different have posed compositional challenges, motivating enrichments to the semantic system (Keenan 1992; Barker 2007). Empirical parallels between these phenomena suggests that insights in one area can and should inform analyses in the other.

\subsection{Event-internal pluractionality}

Cusic (1981) and Wood (2007) highlight another parameter of variation: event-external or eventinternal pluractionality. All forms discussed so far have been cases of event-external pluractionality: roughly speaking, we have a plurality of events of the same kind. Intuitively, event-internal pluractionals are atomic events that are nevertheless comprised of smaller parts. The English words nibble, flutter, juggle, applaud seem to have this property: a single juggling event is divided in time into many moments at which a throwing event happened.

Many languages of the world have morphemes that indicate this kind of event-internal pluractionality. The derivations in (49) provide examples from Syrian Arabic that illustrate.

$$
\begin{aligned}
& \text { a. safa? 'to clap, slap' } \rightarrow \text { saffa? 'to applaud/clap in rhythm' } \\
& \text { b. kasar 'to break in two' } \rightarrow \text { kassar 'to break to pieces' }
\end{aligned}
$$

(Syrian Arabic, Cowell 1964)

Wood (2007) describes a range of properties that distinguishes event-internal pluractionality from event-external pluractionality. First, there are aksionsart restrictions that apply only to eventinternal predicates: they appear on semelfactives and possibly achievements (as in (49a) and (49b), respectively), but do not appear on accomplishments. Second, event-internal pluractionals generally carry the requirements of multiplicity and density. Whereas event-external pluractionals seem 
to be felicitous with at least two repetitions of the event, event-internal pluractionals generally entail numerous sub-parts in quick succession. Third, a subclass of event-internal pluractionals carry the entailment that the series of repetitions share a common goal or result. Again, this can be seen in the examples above: in (49a), keeping rhythm is a goal that can be accomplished through a plurality of claps; in (49b), repetitive breaking yields a single result-state.

Event-internal pluractionals also differ from event-external pluractionals with respect to compositional properties. In particular, we saw above that event-external pluractionals may allow (or require) distribution across the members of a plural licensor-a different subevent associated with each participant. This is never possible with event-internal pluractionals. The pluractional in (49b), for example, must describe the breaking up of a single object, not multiple objects being broken a single time. Similarly, in (50), the Kaqchikel suffix glossed $\mathrm{Ca}$ ' marks event-internal pluractionality. The sentence must mean that each individual glanced at the speaker several times; it cannot be used to describe a situation in which each person glanced at the speaker once.

(50) Xikitz'et-etz'a' ri winaqi'

look.at-Ca' the people

'The people kept glancing at me.'

(Kaqchikel, Henderson 2017)

These observations suggest an analysis in which event-internal pluractionals are in fact atomic, but have a temporal/spatial trace that can be divided into small parts (Henderson 2017). The expression in (51) sketches the meaning of an event-internal pluractional marker. We let $\tau$ be a function that gives the temporal or spatial trace of an event-i.e., when and where it occured. The function 'fine-partition' returns a set of overlapping intervals that cover this area of space-time. Event-internal pluractionals entail that a given event occurred at each of these subintervals.

$$
\lambda V \lambda e .|e|=1 \wedge \exists P\left[\text { fine-partition }(P, \tau(e)) \wedge \forall t \in P\left[\exists e^{\prime}\left[t=\tau\left(e^{\prime}\right) \wedge V\left(e^{\prime}\right)\right]\right]\right]
$$

'Given a predicate $V$, return the set of atomic events whose temporal (or spatial) trace can be divided into small parts, each of which contains a $V$-ing event.'

(cf. Henderson 2017)

Notably, this definition differs from the one for event-external pluractionality in (19) in a critical way: the output of (19) is a set of plural events $(|e|>1)$; the output of (51) is a set of atomic events $(|e|=1)$. This has compositional consequences. Notably, when a plural individual is an argument of a plural event, a cumulative reading is allowed in which each atomic individual associates with a different subevent. For event-external pluractionals, this allows the participant-key reading. For event-internal pluractionals, all arguments of the plural individual must be associated with the same, atomic event.

\section{Conclusion}

Despite pertaining to different domains of objects - events or individuals_-pluractional verbs and distributive numerals share a core collection of parallel semantic properties. In both cases, they mark an object as a distributive share, and may put restrictions on what can serve as a distributive 
key. Compositionally, both constructions act as a plurality filter; this means that they cannot induce variation in plain indefinites, and that multiple markers can appear redundantly in the same sentence. Pluractional constructions also raise a number of compositional questions. Of note, they may be licensed by operators that distribute down to atomic individuals. We provided evidence in favor of an analysis in which distributive numerals and pluractional verbs take scope above these distributive licensors, and discussed several possible implementations. Finally, we outlined parallels with the adjectives same and different, and discussed cases of event-internal pluractionality, where internal structure may nevertheless be predicated of atomic events.

\section{References}

Balusu, R. (2005). Distributive reduplication in Telugu. In Davis, C., Deal, A. R., and Zabbal, Y., editors, Proceedings of the 36th Annual Meeting of the North East Linguistic Society (NELS 36), pages 39-53, Amherst, MA. University of Massachusetts GLSA Publications.

Bar-El, L. (2002). Plurality in Skwxwú7mesh (Squamish Salish): A look at reduplication. University of Massachusetts Occasional Papers in Linguistics, 25.

Barker, C. (2007). Parasitic scope. Linguistics and Philosophy, 30(4):407-444.

Brasoveanu, A. and Farkas, D. (2011). How indefinites choose their scope. Linguistics and philosophy, 34(1):1-55.

Cable, S. (2014). Distributive numerals and distance distributivity in Tlingit (and beyond). Language, 90(3):562-606.

Cabredo Hofherr, P. and Laca, B. (2012). Introduction - event plurality, verbal plurality and distributivity. In Cabredo Hofherr, P. and Laca, B., editors, Verbal plurality and distributivity. de Gruyter, Berlin, Boston.

Champollion, L. (2015). Overt distributivity in algebraic event semantics. Ms. New York University.

Charlow, S. (to appear). Post-suppositions and semantic theory. Journal of Semantics.

Choe, J.-W. (1987). Anti-quantifiers and a theory of distributivity. PhD thesis, University of Massachusetts, Amherst, MA.

Cowell, M. W. (1964). A reference grammar of Syrian Arabic. Georgetown University Press, Washington, DC.

Cusic, D. D. (1981). Verbal plurality and aspect. PhD thesis, Stanford University, Stanford, CA.

Davidson, D. (1967). The logical form of action sentences. In Rescher, N., editor, The logic of decision and action, pages 81-95. University of Pittsburgh Press, Pittsburgh, PA.

Deo, A. (2009). Unifying the imperfective and the progressive: partitions as quantificational domains. Linguistics and philosophy, 32:475-521.

Dixon, R. (1972). The Dyirbal Language of North Queensland. Cambridge University Press, Cambridge, UK.

Farkas, D. F. (1997). Dependent indefinites. In Corblin, F., Godard, D., and Marandin, J.-M., editors, Empirical issues in formal syntax and semantics, pages 243-268, Bern, Switzerland. Peter Lang.

Farkas, D. F. (2015). Dependent indefinites revisited. Talk at the Workshop on Distributivity, Paris. 
Ferreira, M. (2016). The semantic ingredients of imperfectivity in progressives, habituals, and counterfactuals. Natural Language Semantics, 24:353-397.

Gil, D. (1982). Distributive numerals. PhD thesis, University of California, Los Angeles, CA.

Hardt, D. and Mikkelsen, L. (2015). Same but different. Linguistics and Philosophy, 38(4):289314.

Hardt, D., Mikkelsen, L., and Ørsnes, B. (2012). Sameness, ellipsis and anaphora. In Aloni, M., Kimmelman, V., Roelofsen, F., Sassoon, G. W., Schulz, K., and Westera, M., editors, Logic, Language and Meaning: 18th Amsterdam Colloquium, pages 341-350, Amsterdam, Netherlands. Springer Berlin Heidelberg.

Henderson, R. (2014). Dependent indefinites and their post-suppositions. Semantics and Pragmatics, 7(6):1-58.

Henderson, R. (2017). Swarms: Spatiotemporal grouping across domains. Natural Language and Linguistic Theory, 35:161-203.

Keenan, E. L. (1992). Beyond the Frege boundary. Linguistics and Philosophy, 15:199-221.

Kimmelman, V. (2015). Distributive quantification in Russian Sign Language. Presentation at Formal and Experimental Advances in Sign Language Theory, Barcelona, Spain.

Krifka, M. (1998). The origins of telicity. In Rothstein, S., editor, Events and grammar, pages 197-235. Kluwer, Dordrecht, Netherlands.

Kuhn, J. (2017). Dependent indefinites: the view from sign language. Journal of Semantics, 34(3):449-491.

Kuhn, J. and Aristodemo, V. (2017). Pluractionality, iconicity, and scope in French Sign Language. Semantics and Pragmatics, 10(6).

Laca, B. (2006). Indefinites, quantifiers and pluractionals. In Linguistik Aktuell/Linguistics Today, pages 191-217. John Benjamins Publishing Company.

Lasersohn, P. (1995). Plurality, conjunction, and events. Studies in Linguistics and Philosophy. Springer Netherlands.

Lepic, R., Börstell, C., Belsitzman, G., and Sandler, W. (2016). Taking meaning in hand: Iconic motivation in two-handed signs. Sign Language \& Linguistics, 19(1):37-81.

Link, G. (1983). The logical analysis of plurals and mass terms: A lattice-theoretical approach. In Bäuerle, R., Schwarze, C., and von Stechow, A., editors, Meaning, use and interpretation of language, pages 303-323. de Gruyter, Berlin, Germany.

Link, G. (1987). Generalized quantifiers and plurals. In Gärdenfors, P., editor, Generalized quantifiers, pages 151-180. Springer, Berlin, Germany. Reprinted in Link (1988), Chapter 4.

Oh, S.-R. (2006). Plurality markers across languages. PhD thesis, University of Connecticut, Storrs, CT.

Parsons, T. (1990). Events in the semantics of English. MIT Press, Cambridge, MA.

Thompson, J. J. (2009). On verbal number in Upriver Halkomelem. Ms. University of British Columbia. Available at http://semanticsarchive.net/Archive/DI2NDZiN/.

van den Berg, M. (1996). Some aspects of the internal structure of discourse: the dynamics of nominal anaphora. PhD thesis, ILLC, Universiteit van Amsterdam.

van Geenhoven, V. (2004). For-adverbials, frequentative aspect, and pluractionality. Natural Language Semantics, 12:135-190. 
Wood, E. (2007). The semantic typology of pluractionality. PhD thesis, University of California, Berkeley.

Yu, A. C. L. (2003). Pluractionality in Chechen. Natural Language Semantics, 11(3):289-321.

Zeijlstra, H. (2004). Sentential negation and negative concord. PhD thesis, University of Amsterdam.

Zimmermann, M. (2002). Boys buying two sausages each: On the syntax and semantics of distance-distributivity. PhD thesis, University of Amsterdam, Amsterdam, Netherlands.

Zweig, E. (2005). The implications of dependent plurals. In Davis, C., Deal, A. R., and Zabbal, Y., editors, Proceedings of the 36th Annual Meeting of the North East Linguistic Society (NELS 36), pages 735-750, Amherst, MA. University of Massachusetts GLSA Publications. 